\title{
THE TRUE MEANING OF FORCE: A FURTHER RESPONSE TO TOM RUYS IN THE INTEREST OF PEACE
}

\author{
Mary Ellen O'Connell
}

I very much appreciate the seriousness with which Tom Ruys read my comments on his article. Rather than convince me that his thesis about Article 2(4) is correct, however, his reply provides further support for the opposing view. Minor force is excluded from Article 2(4) but regulated under other legal principles. Here are some examples:

- He accepts that there are many cases where states and courts have treated low level uses of force as regulated under rules other than Article 2(4). He also argues, and I agree, that some cases are unclear as to whether they support an Article 2(4) threshold or not. Yet, he fails to deal with the really important point in my comment that the great weight of authority clearly supports the threshold. In his reply he even cites with favor the recent report of the Independent International Fact-Finding Mission on the Conflict in Georgia, but the report supports the view that low level uses of force fall below the Article 2(4) threshold.

- Ruys concedes that some low-level uses of force are outside Article 2(4). In his reply he provides a new hypothetical of such a minor use of force, a bar fight in Afghanistan between soldiers of different nationalities. He says it is a matter of common sense that such a use of force is excluded from Article 2(4). Yes, common sense is one of the reasons to conclude low-level force is excluded. Given that he agrees on this, his article should be about where the threshold is, not an argument that there is no threshold at all. I argue that various other rules of international law from the principle of non-intervention to human rights law to the law of countermeasures indicate where the threshold is. In his reply he takes up an example I provide on "targeted killing," asking where is the legal distinction between knifing an individual and launching a Hellfire missile at an individual, as opposed to launching a Hellfire at a group of people - the example I used. I categorize all Hellfire attacks as covered by Article 2(4) because of the amount of firepower involved. The Hellfire was developed as a tank-killing weapon. The number of persons targeted is not as significant as the fact the Hellfire involves more too much firepower to conform to the rules governing lawful law enforcement (police) deployment of lethal force. Lawful deployment of a Hellfire must comply with one of the exceptions to Article 2(4).

- Saying minor force is excluded from Article 2(4) is not the same as saying such force is lawful. The example just mentioned of knifing an individual, say by the intelligence services of one state acting on the territory of another state, implicates non-intervention, human rights, and countermeasures, among other rules relevant to regulating minor uses of force. In his reply, Ruys criticizes the ade-

* Robert and Marion Short Professor of Law and Research Professor of International Dispute Resolution-Kroc Institute, University of Notre Dame. Originally published online 4 Sept. 2014

ASIL and Mary Ellen O’Connell (C) 2014 
quacy of some of this law. No doubt some of the law is inadequate, but that is a different issue from the one he is examining, which is what law applies to minor uses of force.

- If Article 2(4) included minor uses of force states could not lawfully employ countermeasures involving minor uses of force in, for example, rescue and arrest efforts. Using force under today's law, which does not include Ruys's proposal to expand the right to use force in self-defense, requires Security Council authorization. This is clearly a problem for his analysis. States simply do not do this. The United States did not go to the Security Council to get permission to try to rescue the American journalist, James Foley, beheaded by ISIL militants in Syria in August or to detain Abu Khattala in Libya in June. Both operations followed the rules regulating lethal force by police and were lawful in my view, but not in Ruys's view of the current law.

Ruys says the Abu Khattala detention does not fit his proposal for expanded self-defense. Why not? The U.S. ambassador to the United Nations asserted it fits under the current version of Article 51. Ruys and I agree that is wrong, but with the addition of "greater flexible" as Ruys proposes, why not? The lead U.S. negotiator at the San Francisco conference who drafted Article 51 wanted it to be narrow in scope and as objective as possible. Ruys's call for greater flexibility introduces the very subjectivity states rejected in 1945.

I accept that Ruys may not have written his article with the purpose of proposing to expand the right to use force in self-defense. I, nevertheless, maintain that it is a critical part of his argument. If he had left it out, readers would see even more clearly that states would, in his view, be required to go to the Security Council for any minor use of force. Moreover, there is real interest in certain government legal and scholarly circles in expanding the right to use force in self-defense. Tom Ruys's proposal regarding self-defense is likely to be read with more interest than his thesis respecting Article 2(4).

President Obama officially justified the use of force in Iraq in August as protection of American nationals and facilities. He did not mention any request for assistance from Iraq.

While it seems to Dr. Ruys that Olivier Corten and I have adopted positions contrary to our known fidelity to the law against force in interpreting Article 2(4) as including a threshold, that is simply not the case. We see minor force as well restricted under general international law. Neither of us proposes expanding the right to use force in self-defense, which really is a dangerous departure. 